\title{
RELATIVISM OF HADITH SCIENCE
}

\author{
Ahmad Fudhaili \\ Syarif Hidayatullah State Islamic University (UIN) Jakarta \\ ahmad.fudhaili@uinjkt.ac.id
}

\begin{abstract}
Hadith science is a relative science and can be developed in accordance with the needs of the era. it is not an absolute science and final. Reliable collectors of hadith also have a role in deciding the acceptance or rejection of hadith among Islamic societies. Similarly with the criticism of matan, there is a hadith that is considered weak (da'if) when viewed from the side of sanad, but its matan is more in line with the Qur'an, compared with the hadith considered strong (sahih) in terms of sanad.
\end{abstract}

Keywords: Science of hadith, da'if, sahih, relative science, matan, sanad, critic

\section{Introduction}

Science grows and evolves according to the needs and the developing of the times. There is nothing absolute in this world except the Substance of Allah SWT. Thus the science of hadith is not absolute and not final in accordance with the needs and the developing of the times. In practically, as if the science of hadith is final and absolute because it is closed for criticism and analysis.

This fact is seen with the concept of a fierce debate about the paradigm of a person in understanding the hadith. One proof of the publication of a book entitled "alDifa' 'an al-Sahihain Difa' 'an Islam" (2003) written by a Moroccan scholar named Muhammad ibn al-Husain al-Hajwi al-Sya'alibi al-Fasi (d. 1376 H.). There is also a book entitled "Taudih Turuq al-Rashad li Hasm Maddah al-Ilhad" (2003) written by Muhammad ibn Ahmad al-'Alawi al-Isma'ili (d.1367 H.). These two references contained criticism and even criticism of those who analyzed or criticized the two books of al-Sahih namely al-Bukhari and Muslim, even impressed that the person who criticized these two sahih books was considered assaulting the religion of Islam.

There is also a contemporary book that has a similar content titled "Difa' 'an Sunnah"(1989) written by Muhammad ibn Muhammad Abû Shahbah and "Al-Radd 'alMan Yunkiru Hujjiyah al-Sunnah"(1989) written by' Abd al-Ghani 'Abd al-Khaliq. This is probably due to the assumption that the science of hadith is absolute and final. On the other hand, there are also scholars who conduct analysis and criticism of the sahihh-alBukhari with all of equipments and standardization set. Among them is the book "Riwayat al-Mudallisin fi Sahih al-Bukhari" (2001) written by 'Awwad al-Khalqa. There is also a book entitled "Namadzij min Marwiyyat Man Khaffa Dabtuhum fi Sahih alBukhari" (2012) written by Tariq Muhammad. These two books prove scientifically that in Sahih al-Bukhari, there are history and problematic narratives that can weaken (da'if) the status of a hadith. This supports that the science of hadith is not an absolute science and it has not been final but a relative and developing science. It is not Sahih ascertained $\underline{S} a \underline{h i} \underline{h}$ in its development and $\underline{d} a^{\prime} i f$ is said da'if in its development.

\section{The Dominance of the Sanad Rules (Hadith Narrator) compared by the Matan (Hadith Material) in the Acceptance of Hadith.}

The scholars of hadith set out the acceptable requirement (maqbûl) a hadith with five conditions. These five conditions are usually expressed as a shaheh requirement of a hadith. The five conditions are: (1) The series of sanad (narrators of hadith) continued. 
With this requirement, it is unacceptable to hadith that are munqati', mu'dal, mu'allaq, mursal, mudallas and mursal khafi. (2) The hadith is narrated by a just narrator. A just narrator means a consistent person (istiqamah) in running his religion, having a noble character, looking after from the characteristics of fasiq and can maintain murü'ah. With this requirement, it is unacceptable to hadith that is matrûk. (3) The Hadith is narrated by the dabit narrators. What is meant by dabit is that a narrator notices when the hadith is recited and understands what is heard and memorizes it, can keep it memorized ever since he heard the hadith from his teacher (tahammul) until he read it back to others (al-ada). A narrator is called hafidz (memories) and a'lim (knowledgeable) when he narrated hadith from his memorization. And he is said to be fähim (understood) when he narrated the hadith from the understanding he had understood (ma'nawi). A narrator should also be able to keep his or her own hadith records of change, either reducing, adding, substituting or exchanging from the original form ('Ajjaj , 1989, 305). With this requirement, it is unacceptable to hadith that are mudraj and maqlûb. (4) There is no awkwardness (syadz) in his content of hadith (matan). Sya'dz means the transmission of a tsiqah person in opposition to the transmission of a more tsiqah person (autsaq minhu) ('Ajjaj , 1989, 305). (5) There is no defect ('Illat) in his eyes. The mu'allal hadith (the defect) is a zahir hadith that does not appear to be a defect, but can be known after extensive research. As mursal hadist considered mausul hadith, mausul hadith considered munqoti' and marfu hadith considered mauquf hadith.

The five requirements mentioned above are acceptable requirements for a transmission. These five requirements are usually used as the definition of hadith sahih which is connected with the narrators of the tsiqah from beginning to end of the sanad without any awkwardness (syadz) and defect ('illat). ('Ajjaj, 1989, 305)

In addition to the above five requirements there are several other requirements that must be added. However, these additional requirements were not agreed upon by the scholars. These additional terms are: (1) The hadith narrator must be a person known as an expert on hadith (Masyhûr bi al-Talab). 'Abdullah ibn' Aun says: "Science (hadith) can not be taken except from a expert person". Abû Zinad says: "I met a hundred trusted men in the city of Medina, but no hadith was taken from them, because they were not experts." This requirement is deemed to have been included in the dabit requirements on the five terms. (2) The hadith narrator has been known as a clever, intelligent person, often hears the hadith and has read it repeatedly. This requirement is deemed to have been covered under the terms of the "absence of 'illat". (3) The narrator must understand the meaning of hadith, if he narrates with meaning. This requirement is deemed to have been included in the dabit requirements. (4) Abu Hanifah requires faqih (have a deep understanding) to all narrators of hadith. (5) Imam Al-Bukhari requires the certainty (tsubût) to hear directly from his teacher. For every narrator, not enough just with the possibility (imkan) to meet his teacher or to live contemporaneously with his teacher. But this requirement belongs only to Imam Al-Bukhari. This requirement makes the position of narration of Imam AlBukhari as the most shaheh narration than others hadith shaheh. (6) There are some narrators in every narration, such as testimony. ('Umar Hasyim, 1995, 44-45).

Even in analyzing each narrator, a researcher must also obey some code of ethics.

\section{Assesment Ethics Code to the Narrator of Hadith}

The rules that must be held in the assessment of sanad (narration of hadith) are: (1) Trusted (amanah) and sincere in deciding the law, because they must explain about the existence of a narrator either the negative or positive; (2) Thorough and careful in making decisions; (3) Hold the code of ethnic; and (4) Global in ta'dil and detailed in tajrih.(Al-Bagdadi, 1988, 101) 
As for the ulama who do criticism (jarh wa ta'dil) must have the following requirements: (1) Alim (knowledgeable), (2) Taqwa, (3) Wara '(including abstaining from the subhat's actions (vaguely legal), (4) Honest, (5) No defects (jarh), (6) No fanatik mazhab. Knowing exactly and deeply the person he criticized. If there are no one of the requirements, then the criticisms are unacceptable. ('Ajjaj, 1989, 269).

At that time, it is difficult for the hadith researchers to make judgments (jarh wa $t^{\prime}$ 'dil) against the narrators of the hadith, or to find new data about their credibility, since the present generation can only know the credibility of a narrator of hadith based on information from the published data.

The data is based on the judgment of others who know about the existence of a narrator of hadith. So in essence, a person who does not know of a narrator of the hadith should believe in the authors of the books which contain biographies of narrations of hadith. We must believe in Imam Al-Bukhari, when we judge a narrator of hadith by using al-Du'afa al-Saghir, or we should believe in Imam Nasā'i when we use the book alDu'afa wa al-Matrukkin or we should believe in al-Razi when we use the book al-Jarh wa al-Ta'dil. Our belief in the authors of the books also applies to those who are the source of the news by the authors of the book.

Although the signs have been established to ensure the authenticity of a hadith and the certainty of the source of transmission which reaches to Rasulullah, so obtaining the shahih status, does not automatically produce as what we are expected.

\section{Proof of Case of Existence of Hadith Depending on the Narrator. Weak narrators (dha'if) in the Book of Sahih.}

The fate of a hadith depends not only on the narration (sanad), but also on the collectors of hadith. There is a hadith narrated by a weak narrator (da'if), but this hadith is included in the book which is considered to be the most valid and the standard of validity of the other book, Sahih al-Bukhari. Perhaps no one suspects a disability on the following hadith, because this hadith is narrated by an unquestioned credibility. In Kitāb al-Raqaq, Bab Yadkhul Jannah Sab'una Alfan bi Ghairi Hisab, Imam al-Bukhari includes a hadith in which there is a narrator named Asid ibn Zaid ibn Najih al-Jammal al-Qurasyi. (A1Bukhari)

This "lucky" Hadith is included in the shahih, although there is a rãwi who is considered weak and should not belong in the sahih. Overall, this narrator has no problem except a narrator Asid ibn Zaid ibn Najih al-Jammal al-Qurasyi, the year of his death is not certain to be presumed that he died before $220 \mathrm{H}$. No one from the scholars of hadith who ta'dil (positive rate) against Asid ibn Zaid.

The commentars of the scholar of hadith about Asid ibn Zaid: (1) Al-Dar Qutni: Da' if al-Hadits (Hadiths are weak); (2) Abû Hatim al-Razi: Yatakallamûn fih (discussed); (3) Ibn 'Adi: Yatabayyanu 'ala Riwayatih al-Da'f(His history is clearly weak); (4) Yahya ibn Ma'in Kadzdzab (Liar); (5) Al-Khatib: Ghair Mardi (not approved); (6) Nasir al- Din al-al-Bani: Put it in his work Al-Silsilah al-Da'ifah; and (7) Jalal al-Din al-Suyûti: Put it in his work Al-Alai al-Masnû'ah 'ala al-Ahadits al-Maudû'ah.

Imam al-Bukhari included Asid ibn Zaid in his sahih-book became a defect for Imam al-Bukhari. But Ibn Hajr Al-'Asqallāni in Fath al-Bari fi Syarh Sahih al-Bukhari says perhaps the imam of al-Bukhari considered Asid ibn Zaid to be a 'just man. This statement may be acceptable because Asid ibn Zaid was one of the teachers of imam alBukhari, but how many other narrations did he get from his teachers but not included in his sahih because of negative judgment on them.

None of the collectors of the hadith put Asid ibn Zaid in their work except to explain the defects contained in the hadith, because the status of jarh Asid ibn Zaid came 
to the category kadzdzab (liar). However, this Hadith is safe because there are supporters of some acceptable narrators (tsiqah). The question is why Imam al-Bukhari includes Asid ibn Zaid in his sahih. If Asid ibn Zaid had not been listed, it had fulfilled all standards of transmission. The inclusion of the name Asid ibn Zaid in the Sahih Bukhari actually weakens the credibility of the Imam al-Bukhari himself, though not the whole transmission of Imam al-Bukhari has become flawed. The possibility of Imam al-Bukhari includes the history of Asid ibn Zaid in his sahih, as it has several strong supporters. If that is the reason why Imam al-Bukhari includes the history of Asid ibn Zayd is not another strong history?

\section{Matan is Good, but sanad is not good defeated with Sanad the Good but matan not good.}

There is a hadith which has a "good" matan but there is a defect in its sanad, defeated with a hadith that has a "less good" matan but has a series of sanad that have no defects. Like matan Hadith :

"There are actually three things that bring bad luck: horses, women and houses" (Al-Bukhari).

Sanad of this hadith is undoubtedly his authenticity, as narrated by imam alBukhari and Muslim imam with various lines of narration. Even other scholars of hadith, such as the Imam al-Nasa'i, amam al-Tirmidzi, Imam Abû Dawûd and Imam Ahmad ibn Hanbal attribute the hadith theme as above in their works. But the material of this hadith is discussed as contrary to the text of the Qur'an of al-Hadid / 57: 22;

The person who states the above hadith contradicts the Qur'an letter al-Hadid/ 22 is' Aishyah ra. (Al-Zarkasyi, , 1980, 104). 'Aisyah also criticized Abû Hurairah as a memorized narrator of this hadith (Ibn Hajr As-Asqallani, 1978, 11). Unfortunately the hadith which contains the rebuttal and the criticism of 'Aisyah against Abû Hurairah is considered da'if (weak) in the munqati status (Munqati' Hadith is a hadith that the chain of its sanad is cut off from any side either the beginning, the middle or the end and belonging to the hadith da'if / weak). because one of its narrators, Makhîl (113 H.), has doubtless met 'Aisyah, then there is between Makhûl with' Aisyah which is not included In the history (Al-Zarkasyi, 1980, 104). While from the science side jarh wa ta'dil no one who judges negative Makhûl. Some scholars' assessments of Makhûl (112 H.): Sa'id ibn 'Abd al-'Aziz (The one who is the most Faqih from Sham), Al-'Ijli (Tsiqah), Ibn Khurrasy (Sadûq), Abû Hatim al-Razi (There is no one in Sham who is more faqih than Makhûl, Ibn Hibban (Insert in the category of a tsiqah, but sometimes he is mudallis), Abu Yunus (Faqih, 'Alim).

There is another narration on another theme which indicates that Makhîl's narration proceeded directly from Aisyah narrated by Imam Ibn Majah: But this narration is commented on by Ibn Hibban that in this hadith there are narrations considered mudallis.

The narration of Abû Dawûd al-Tayalisi and Ahmad's imam's narrations is a criticism of Aisyah against the narration of Abû Hurairah about unlucky things. In the narration of Abû Dawûd al-Tayalisi, 'Aisyah immediately criticized Abû Hurairah's transmission that Abû Hurairah did not hear the complete hadith, whereas in Imam Ahmad's narration,' Aisyah criticized Abû Hurairah's history with the verses of the Qur'an (al-Hadid / $57: 22$ ) as well as other reports that he heard from Rasulullah saw.

Hadiths narrated by Imam al-Bukhari and Imam Muslim are through the line of 'Abdullah ibn' Umar (d. 73 H) and Sahl ibn Sa'ad al-Sa'idi (d. 88 H), Narrated by Abû Dawûd al-Tayalisi and Imam Ahmad is through the path of Abû Hurairah which contains the criticism of 'Aisyah against it. This means that this hadith is not only heard by Abû 
Hurairah, but also heard by 'Abdullah ibn' Umar (d.73 H.) and Sahl ibn Sa'ad al-Sa'idi (d $88 \mathrm{H}$.). Confronting the hadith of shaheh with the hadith of Dhaif or between the Qur'an and the shaheh hadith is not possible, because it is unbalanced and one of them will be eliminated. Shaheh hadith with dha'if hadith will be "won" by shaheh hadith. The shaheh hadith with the Qur'an will be "won" by the Qur'an. If the text of the Qur'an is submitted then even shaheh hadith will be defeated.

The narration of Abû Dawûd al-Tayalisi and Imam Ahmad are lower in rank than the hadiths of Imam al-Bukhari and Muslim Imams (Muttafaq 'alaih), but the hadith of the narrations' Aisyah quoted by Imam Ahmad are very relevant to the hadith narrated by al-Bukhari And Muslim. The 'Aishyah' hadith narratives can not be confronted with the hadith narrations 'Abdullah ibn' Umar (d.77 H.) quoted by imam al-Bukhari and Muslim imams for having no quality similarities between them (between shahih and dha'if). Without using the hadith narrated Aisyah, the narration of Imam al-Bukhari and Muslim Imam through' Abdullah ibn 'Umar can still be questioned using the Qur'anic verse, alHadid / 57: 22, contained in the hadith narration ' Aisyah and is the argument 'Aisyah in criticizing the hadith narrated Abu Hurairah.

\section{Conclusion}

The impression of the contradiction between the text (matan hadith) which shaheh its sanad with the Qur'an is addressed by 'Asiyah not making Aisyah narration be superior or balanced with the narration of Hadith of Al-Bukhari and Muslim, because history 'Aisyah still considered lower status compared hadith narrated by al-Bukhari and Muslim. This fact illustrates how a narrator strongly determines the fate of a hadith.

Although the criticism of 'Aisyah using the Qur'anic verse on the narration of Abû Hurairah makes the hadith a "balanced counter" to the narrations of Al-Bukhari and Muslims through the' Abdullah ibn 'Umar (d.73 H.), by looking at the criticism meteri (Matan hadith), namely the letter of al-Hadid / 57: 22. This comparison makes some scholars believe that the history of 'Aisyah is closer to the truth, Insya Allah, because it is more in line with the Prophet's prohibition. In general about tatayyur (Al-Zarkasyi, 1980, 104), and in accordance with the verses of al-Qur'an al-Hadid / 57: 22.

This fact also proves that the trusted collectors of hadith also have a role in deciding the acceptance or rejection of hadith among Islamic societies, since Asid ibn Zaid which is considered negative by the scholars of hadith may occupy a position of honor and fortunate to be included in the collection of Hadiths of Imam Al-Bukhari which considered to have very strict requirements.

It also proves that the science of hadith is a relative science and can be developed and developed in accordance with the needs and times of development is not an absolute and final science. This supports that the science of hadith is not an absolute science and it has not been final but a relative and developing science. It is not Sahih ascertained $\underline{S} a \underline{h} \underline{i} \underline{h}$ in its development and $\underline{d} a^{\prime} i f$ is said $\underline{d} a^{\prime} i f$ in its development.

\section{References}

Al-Asqallani, Ibn Hajr. 1978. Fath al-Bari bi Syarh al-Bukhari. Cairo: Maktabah alQahirah.

Al-Bagdadi. 1988. Kitab al-Kifayah fi Ilm al-Riwayah. Beirût: Dar al-Kutb al-Ilmiyah. Al-Bukhari. N.Y. Matan al-Bukhari Masykul bi Hasyiyah al-Sindi. Beirût: Dar el-Fikr. Al-Fasi, Muhammad ibn al-Husain al-Hajwi al-Sya'alibi. 2003. 'al-Difa " an al-Sahihain Difa' 'an Islam. Beirût: Dar Ibn Hazm.

Hasyim, Ahmad 'Umar. 1995. Qawa'id al-Hadits. Cairo: Dar al-Syabab li al-Taba'ah. 
Al-Isma'ili, Muhammad ibn Ahmad al-'Alawi. 2003. Taudih Turuq al-Rashad li Hasm Maddah al-Ilhad. Beirût: Dar Ibn Hazm.

Al-Khaliq, 'Abd al-Ghani 'Abd. 1989. Al-Radd 'al-Man Yunkiru Hujjiyah al-Sunnah. Cairo: Maktabah al-Sunnah.

Al-Khalqa, 'Awwad. 2001. Riwayat al-Mudallisin fi Sahih al-Bukhari. Morocco, Dar Basya'ir al-Islamiyyah.

Al-Khatib, Muhammad 'Ajjaj. 1989. Us

Muhammad, Tariq. 2012. Namadzij min Marwiyyat Man Khaffa Dabtuhum fi Sahih alBukhari. Beirut: Dar Kutub al-'Ilmiyyah.

Al-Naisabûri, Muslim Ibn Hajjaj. 1993. Sahih Muslim. Beirut: Dar al-Fikr.

Al-Qasimi, Muhammad Jamaluddin. 1979. Qawa'id Tahdits min Funûn Mustalah alHadits. Beirût: Dar al-Kutub al-'Ilmiyah.

Shahbah, Abû. 1989. Difa' 'an Sunnah. Cairo: Maktabah al-Sunnah.

Syakir, Ahmad Muhammad. 1994. Al-Ba 'its al-Hatsits. Beirût: Dar al-Kutb al-Ilmiyah.

Al-Zarkasyi, Badr al-din. 1980. Al-Ijabah li Irad ma Istadrakathu 'Aisyah 'ala Sahabah. Beirût: al-Maktabah al-Islami. 